\title{
Non timber tree products: alternative source of livelihood in man-crop/grass-livestock-tree/shrub continuum of arid regions
}

Volume 2 Issue 4 - 2017

\section{Introduction}

For the most of recorded history, people have valued forest and trees not for wood, but for other products. Ancient writings from China, Egypt and India record a wide variety of use for forests and trees, and compilation of botanical knowledge from western Asia were prized by the ancient Greeks (Wickens, 1990). Whereas wood products have become major international commodities in modern times, non-timber tree produce (NTTP) often referred as non-wood forest produce rank among the oldest traded commodities. ${ }^{1}$ Ancient Egyptians important gum Arabic from Sudan for use in paints and mummification process. ${ }^{2}$ International trade in sandalwood oil dates back to the twelfth century A. D. Why have modern science and Governments overlook the importance of NTTP wealth for so long? The answer is three fold. First, most of these products are used mainly for rural subsistence or local markets. They often go unrecorded in official statistics, which focus on nationally traded goods. ${ }^{3}$ Second, because modern Government administration have divided these products among forestry, agriculture and horticulture and therefore, statistics do not recognize even nationally and internationally NTTP. Finally, modern forestry has favoured timber and large enterprises, and generally NTTPs as incidental. However, the fact is that for most of the world's rural households NTTPs provides essential food and nutrition, fodder, fuel, medicine, thatch and construction materials, mulch and non-farm income. ${ }^{4}$ Poor households, in particular, depend on these products for their livelihood, especially in developing and under developed countries.

\section{Scenario of hot Indian arid region}

The hot arid regions of India lie between $24-29^{\circ} \mathrm{N}$ latitude and $70-76^{\circ} \mathrm{E}$ longitude, covering an area of 31.7 million ha, and involving seven states: Rajasthan, Gujarat, Punjab, Haryana, Andhra Pradesh, Karnataka and Maharashtra. In total, $11.8 \%$ of the country is under hot arid environment. ${ }^{5}$ The arid regions of Rajasthan, Gujarat, Punjab and Haryana together constitute Great Indian Desert, better known as Thar Desert. In Rajasthan, Thar desert is spread over in an area of 1, 96,150 sq. $\mathrm{Km}$ in 12 arid western districts, which is also referred as principal hot arid region of the country. ${ }^{6}$ Arid western Rajasthan is loaded with 2.71 million human and 11.76 million livestock population. Thus, human: livestock ratio in the region is $1: 0.43$, increasing $1: 0.50$ in extreme west against 1:0.5 for rest of the country. ${ }^{7}$ There has been a continuous increase in density of livestock across the region and all kind of animals excepting cattle and camel. In arid western Rajasthan, probably more animals feed on trees and shrubs than on grasses/herbs and pasture legumes. The leaf fodder of some trees and shrubs of the region is almost as nutritious as that of leguminous crops. There are certain tree species, the leaf fodder production from which can be comparable with grass production from pastures and range lands. Besides, trees and shrubs have the potential to grow under harsh climatic conditions and on the lands where arable crops, and annual

\author{
JC Tewari,' Kamlesh Pareek,' Shiran K,' MM \\ Roy' \\ 'ICAR- Central Arid Zone Research Institute, India \\ ${ }^{2}$ ICAR-Indian Sugarcane Research Institute, India
}

Correspondence: JC Tewari, ICAR- Central Arid Zone Research Institute, Jodhpur- 342003, India, Email drjctewari@gmail.com

Received: June 01, 2017 | Published: June 30, 2017

grasses cannot grow successfully. The cattle, buffaloes and sheep are grazers and feed upon pasture land production, which often also contains leaves of tree/shrubs species, whereas goats and camels are pre-dominantly browsers and thrive upon top feed. ${ }^{8}$ Thus, leaf fodder of trees and shrubs is important life support of livestock in this part of the country and such the leaf fodder is most important (NTTP) of man-crop/grass-livestock-tree/shrub continuum in hot arid ecosystems. Principal hot arid regions of the country i.e. arid western Rajasthan is most highly vegetated desert of the world and tree based farming commonly referred as agro forestry is life line of the region. In arid western Rajasthan the forest cover is almost legible and only trees and shrubs out-side the forests form main woody vegetation complex therefore, we have used term non- timber tree produce (NTTP) instead non-timber forest products (NTFP). In addition to leaf fodder of tree/shrubs, the fuel- wood is another most important NTTP as $70 \%$ of households are dependent on fuel wood for their cooking and heating energy needs. ${ }^{4}$ Other NTTP which are directly related to livelihood of rural folk in the region are: natural gums and resins; pods; fruits and seeds and honey collection.

\section{Leaf fodder: the most prized Nttp}

For livestock population of arid western Rajasthan the requirement of air dried grasses and crop residue is estimated to be 30.8 million tonnes. ${ }^{7}$ In addition to this requirement, 8.4 million tonnes of top feed is also required annually. Of the 30.8 million tonnes/year feed required by the grazers, at least 4.0-4.5 million tonnes of green forage is needed to optimize production from lactating cattle and buffaloes in the region. ${ }^{9}$ There is perennial shortage of 28 million tonnes/year of green fodder in the region, which is nearly 40 percent of gross production. ${ }^{10}$ This may rise to $80-90 \%$ during extreme drought years requiring large volumes of import of fodder from neighbouring states.

\section{Utilization of tree leaf fodder in farming} systems of arid regions: case studies

Baorli-bambore watershed: prosopis cinearia based traditional agro forestry system: Baorli-Bambore watershed is a small 
hydrological unit of 870 ha located $39 \mathrm{~km}$ west of Jodhpur in arid western Rajasthan. ${ }^{11}$ The watershed is comprised of three villages viz., Ajit Nagar, Bambore and Tulesar with a human population of 1417 and livestock population of 1392 animals, equivalent to 696 adult cattle units. Estimated the annual requirement of fodder in the watershed was $1400 t$ and that of concentrate 400t. Density of trees of various tree/shrubs species on the farmers' fields and as well as fodder production was worked out. The leaf fodder production on the farmers' fields was in order of $427.12 \mathrm{~kg} \mathrm{ha}^{-1}$ year $^{-1}$ (Table 1). The concentrate (feed) required $-400 \mathrm{t} / \mathrm{year}$ for the livestock in the whole watershed came through two channels: $60 \%$ was purchased from the market and $40 \%$ came from husks of grain crop. Of the total demand of fodder, $28.6 \%$ is met by the leaf fodder available from trees/shrubs. According to Shankarnarayan,,$^{12}$ the traditional agro forestry system in arid and semi-arid region that supplies leaf fodder to the tune of $33 \%$ of total livestock demand in a given area, is sustainable in terms of fodder yield. The present example clearly indicated that farming systems in arid regions of the country are highly dependent on tree leaf fodder for sustenance of livestock.

Table I Leaf fodder production by way of lopping and pollarding of trees/ shrubs on crop fields in Baorli-Bambore watershed

\begin{tabular}{lll}
\hline Species & $\begin{array}{l}\text { Leaf fodder } \\
\text { production } \\
\text { individual }^{-1} \text { year' }\end{array}$ & $\begin{array}{l}\text { Leaf fodder } \\
\text { production } \\
\left.\mathbf{h a}^{-1} \mathbf{~} \mathbf{r}^{\prime}\right)\end{array}$ \\
\hline Acacia jaquemontii & 1.26 & 0.29 \\
Acacia nilotica & 12.66 & 28.23 \\
Acacia senegal & 2.5 & 3.32 \\
Azadirachta indica & 22 & 29.26 \\
Balanites aegyptiaca & 0.35 & 0.04 \\
Capparis decidua & 1.11 & 1.44 \\
Cordia mixa & 7.25 & 0.72 \\
Prosopis cineraria & 40.3 & 349.4 \\
Tecomella undulata & 7 & 7.7 \\
Ziziphus rotundifolia & 9.55 & 5.06 \\
Salvadora oleoides & 16.62 & 1.66 \\
Total & - & 427.12 \\
\hline
\end{tabular}

Village danta-ramgarh, prosopis cineraria -acacia nilotica based traditional agro forestry system

Located in transitional belt between arid and semi-arid regions, village Danta-Ramgarh is spread over in an area of 2195 ha and is one of the largest villages in the area. The village had 864 households with a total human population of 5103. The livestock population of the village was 3040 . On the basis of tree density on farmers fields and quantification of leaf fodder done at the time of lopping of trees, it was estimated that total top feed production from crop fields was $2062.4 \mathrm{t} \mathrm{ha}^{-1}$ year $^{-1}{ }^{5}$ The total annual fodder consumption by livestock in the village was to the tune of $6245.0 t$. The data indicated that of the total fodder demand of livestock in the village, $33 \%$ was met by tree leaf fodder. Thus, tree leaf fodder is very important in mixed croplivestock based farming systems of the arid region.

The tree species on the agricultural fields have been much valued for their:
a. High palatability of leaves,
b. High foliage nutrient content and
c. Good response to lopping in terms of foliage growth.

\section{Tree leaf fodder in hot arid regions: some important aspects}

In general, throughout the hot Indian arid regions, native tree species are very few and slow growing. Moreover, hostile environmental conditions do not support much required natural regeneration of trees (Tewari et al. 1989). The introduction of adaptable and relatively fast growing tree species from iso-climatic regions of the world and also from other parts of India initiated in mid 1950s. ${ }^{13}$ In the process, evaluation and screening of more than 200 trees and shrub species have been accomplished. At the moment thirty-six tree species, the leaves and pods of which are used as fodder are found growing in arid western Rajasthan, of which very few are native to this region. For hot arid areas, the concept of forestry or agro forestry in relation to tree/shrubs is different in many ways. In fact, it is basically concerned with management of trees and shrubs for conservation, and for limited production objectives such as leaves for livestock fodder, wood for fuel and fencing material and seeds/pods for human and as well as livestock diet. The thirty-six tree species mentioned earlier, whose leaves and pods are used as fodder, exhibited different growth performance, utilization age and need of protection during early growth phases (Table 2). Above discussion clearly indicated that leaf fodder is the most prized NTTP of arid region, where only $36 \%$ tree and shrub species are native to this region, rest are introduced either from iso-climatic regions of the world or other drier parts of the country. In general native species provide high quality of leaf fodder then the introduced ones.

\section{Fuel wood}

\section{Essential NTTP for rural folks}

Farmers in hot arid tropics cultivate arable crops in association with tree species since time immemorial. These extensive agroforestry systems were capable to meet the fuel-wood needs for the farmers only 30 to 40 years back. ${ }^{14}$ The tremendous increase in human and livestock population as well as associated demand in the last few decades is now marching towards fuel wood crisis. It is estimated that $70 \%$ rural households still depend on fuel wood for their cooking and heating energy needs throughout the year. In the villages of the hot arid regions of Indian, two major sectors comprised the fuel wood supply system: private collection from farmers' own agricultural fields and collection from extra- territorial areas which do not come under any land use category of the village. Both sectors did not have any formal organisation in terms of rural forestry management. The supply system of fuel wood is neither documented nor monitored or regulated in any part of the arid regions of India.

\section{Utilization of domestic fuel in Hot Indian arid region}

\section{Case study of village 'Sar'}

Majority of land in this village is sandy plain however, at certain location terrain is undulating. Total areas of village 2327 ha of which $81.7 \%$ under arable crop production in form of Prosopis cinearia based traditional agro forestry system..$^{15}$ Total house-holds in the villages were 356 with the total human population of 2614 . The total livestock population of the village was 7867 . Estimated use of fuel wood in entire village for one year is set on Table 3. Prosopis juliflora wood is collected in a very large quantity as fuel form of extra-territorial collection. The value of fuel wood consumption and availability from the available data for the village 'Sar' exhibited a deficit of 485.04t/ 
year. Thus, with regard to consumption, availability of fuel wood was less for the entire village. However, when respondent were asked whether they got sufficient fuel for their cooking and heating needs, $92 \%$ felt that there was not scarcity of fuel, $4.7 \%$ were of the opinion that fuel availability was less than their actual needs and $3.3 \%$ were unable to express their opinion. Thus, it appears that sufficient fuel was available in household for cooking and heating in terms of the total biomass burnt. Majority of fuel wood is coming from extra-territorial collection rather than the trees on farmer's field. The work- out deficit of $26.9 \%$ was met by two source, animal dung cakes (dry) and crop residues. As the entire village is rain fed, crops are grown only during the monsoon season. Crop residues were largely used as livestock fodder; either green or mixed calculated value of crop residue used as fuel was $55.1 \mathrm{t} /$ year or $0.2 \mathrm{t} /$ household/year. On an average, $1.2 \mathrm{t}$ dry animal dung/household/year or $430.0 t /$ year for whole village were used as fuel. The total annual dung (dry) production from the entire livestock population was estimated to be $1578.4 \mathrm{t}$ or $4.4 \mathrm{t} /$ household/ year. Thus, the amount of dry dung which is burnt accounted for $27.3 \%$ of the total dry dung production. Had the required amount of fuel wood be available to household, this substantial quantity (4.4t/ household/year) of dry dung would have reached the crop fields. Thus, the use of $27.3 \%$ of total dry dung production for fuel deprived crop fields contributed nutrient to the soil. Dry dung also increases organic matter, importance soils structures, soil biota and water holding capacity. Thus, domestic cooking in village 'Sar' is based entirely on fuel wood $(73.1 \%)$ and demand of this important NTTP is bound to increase in future due to ever increasing population (both human and livestock) and their associated demands. To regulate fuel wood supply need of villagers, it should be very clear to the concerned state government agencies like revenue department, forest department and district rural development agencies that the rights which comprise tree tenure are as complex as, and quite separate from, the rights that comprise land tenure. In entire arid western Rajasthan all the revenue lands, (often referred to as waste land, village CPRs) and forest land support only degraded woody vegetation, mainly $P$. juliflora which contributed $68.6 \%$ of total fuel wood supply to village 'Sar'. Above discussion clearly reflected the importance of this NTTP in the life support of rural folk in arid western Rajasthan Table 4 included some important fuel wood, seed/ fruits and other NTTP commonly available in hot arid region. These tree species are intricately associated with livelihood of rural folk in one way or other. These entity NTTP has satisfied the need of human and as well as livestock in hot arid region since time immemorial. However, they are currently receiving focused attention from conservationists, policy makers, scientists, etc. Due to their role in socio-economic and as well as in livelihood improvement of primary stakeholders, mainly rural folks.

\section{Natural resins and gums}

Hot arid regions especially, the principal Thar Desert region, also referred as arid western Rajasthan is repository of natural resins and gums exuding tree species. Acacia Senegal, the source of gum Arabic is found in abundance in entire arid western Rajasthan. ${ }^{16}$ In natural case the gum Arabic production from $A$. Senegal trees is on an average about 15 to $25 \mathrm{~g} /$ tree, however the gum induction technology has changed the face of gum Arabic production in arid western Rajasthan during last five years. Many potential areas having very good cover of A. Senegal have been identified. In parts of district Barmer, Nagaur, Jodhpur and Jaisalmer and they are now producing gum Arabic just like gum gardens of Sudan and Nigeria. ${ }^{17}$ The data set in Table 5 provide glimpses of how farmers of 45 villages earning additional income from gum Arabic by using CAZRI gum inducing technique.
The data given in Table 5 indicated that farmers on an average earned additional income of Rs. 1.23lacks/villages/year by the sale of gum Arabic as their NTTP. In addition to A. Senegal, there are number of other natural resins and gums producing tree species in hot arid region. Some of them have already listed in Table 4. Most important lesser known other edible gum producing tree species identified by CAZRI, Jodhpur in hot arid region are: Acacia jacquemontii, A. tortolis, A. nilotica Anogeissus pendula, A. rotundifolia, and Prosopis cinearia. Where gum Arabic and gum from A. jacquemontii at present sold in local town markets nearby villages @ Rs. 1000/kg, the gum from other trees on an average are sold @ Rs. 400-500/kg. Appropriate exudation, collection, simple grading and marketing of these gums provide farmers substantial additional income by sale of these NTTP. Likewise, collection and marketing of oleo-resin produced from Boswellia serrata and Commiphora wightiiare having high medicinal values provide good return to farmers.

\section{Seeds, pods and fruits}

The fruits and seeds of many multipurpose tree species are used as a vegetable in hot arid region. $P$. cinearia and $A$. Senegal are spectacular example, where pods and seeds of the species, respectively are used in human diet from poor households ${ }^{18}$ to elite class. Dried pods of $P$. cinearia commonly known as Sangari is sold in local market@ Rs. 250- 300/ kg and likewise, seeds of $A$. Senegal commonly known as Kummat seeds are sold @ Rs. 100-125/kg in local market. Both these NTTPs have huge local and as well as national market but there is no official statistics regarding their trade and commerce. Such state of affairs has created blind spot as far as impact of NTTPs in sustainable livelihoods of rural folks. Capparis decidua (commonly known as Kair or Karil) fruits are considered highly medicinal and its pickle is sold throughout the country. The species is most common constituent of dry tropical thorn forests as per the classification of Champion and Seth. Likewise Ziziphus species and Salvodora species provide nutritious fruits, which are other lesser known NTTPs, especially of hot arid zone. In addition to discussed NTTP there are many other examples where trees and shrubs provide a range of NTPP, which also include medicinal plants. Thus, NTTPs always provide some source of income to rural folk in one way or other. ${ }^{19-21}$

\section{Summing up}

In local, urban, national and international markets NTTPs including medicinal plants contributes substantially to national economy growth. NTTPs are therefore important to three main groups:

Rural population (the largest group) who have traditionally used these items for livelihood, and social and cultural purpose urban consumer (smaller group but expending rapidly) who purchase these items. Traders, the product processors whose number in the NTTP sector increase as urban market for these products grow. Involving communities in managing NTTPs is not simply an equity issue; it is an issue of wise resource use. Failure to do so has broad consequences in future. Therefore, community participation is needed for sustainable NTTPs management for several reasons.

The most important issues are:

\section{Private property situations}

There should be no restriction in collection of NTTPs from farmers and other stakeholders own private properties e.g. agricultural industries, fruit plantations, agro-forest. 
Table 2 Origin and silvi-culturalfeaturesof tree/shrub species of arid regions which provide nutritious leaf fodder

\begin{tabular}{|c|c|c|c|c|c|}
\hline Species & Origina & Growth rateb early & Late & Browsing Preference/need of protectionc & Utilization age (Years) \\
\hline Acacia aneura & I & 4 & 5 & $\mathrm{n}$ & $6-20$ \\
\hline Acacia leucophloea & $\mathrm{N}$ & 4 & 4 & $\mathrm{n}$ & $12-85$ \\
\hline Acacia nilotica & $\mathrm{N}$ & 5 & 6 & y & $15-100$ \\
\hline Acacia senegal & $\mathrm{N}$ & 3 & 6 & y & $5-19$ \\
\hline Acacia tortilis & I & 7 & 6 & $\mathrm{n}$ & $8-20$ \\
\hline Ailanthus excelsa & O & 4 & 7 & y & $10-20$ \\
\hline Albizia amara & O & 7 & 6 & y & $12-60$ \\
\hline Albizia lebbeck & O & 7 & 5 & y & $10-75$ \\
\hline Anogeissus pendula & O & 4 & 6 & $y$ & $15-75$ \\
\hline Azadirachta indica & $\mathrm{N}$ & 5 & 7 & $y$ & $10-70$ \\
\hline Balanites aegyptiaca & I & 3 & 6 & $\mathrm{n}$ & $10-25$ \\
\hline Boswellia serrata & O & 3 & 4 & $y$ & $8-60$ \\
\hline Capparis decidua & 1 & 3 & 4 & $\mathrm{n}$ & $8-35$ \\
\hline Cassia fistula & O & 7 & 5 & $y$ & $10-55$ \\
\hline Cassia siamea & O & 8 & 6 & $\mathrm{n}$ & $5-25$ \\
\hline Colophospermum mopane & 1 & 8 & 8 & $y$ & $4-28$ \\
\hline Commiphora wightii & I & 2 & 4 & $y$ & $5-30$ \\
\hline Cordia sp. & O & 4 & 6 & $y$ & $5-25$ \\
\hline Dalbergia sissoo & O & 5 & 6 & $y$ & $15-35$ \\
\hline Dichrostachys nutans & O & 6 & 7 & $\mathrm{n}$ & $5-18$ \\
\hline Emblica officinalis & O & 5 & 5 & $y$ & $10-40$ \\
\hline Eucalyptus camaldulensis & 1 & 4 & 6 & $\mathrm{n}$ & $12-24$ \\
\hline Ficus religiosa & O & 5 & 7 & $y$ & $18-100$ \\
\hline Grewia tenax & $\mathrm{N}$ & 3 & 5 & $y$ & $6-16$ \\
\hline Hardwickia binata & O & 5 & 7 & $y$ & $10-40$ \\
\hline Holoptelea integrifolia & O & 4 & 5 & $y$ & $16-60$ \\
\hline Pongamia pinnata & O & 4 & 7 & y & $10-65$ \\
\hline Prosopis cineraria & $\mathrm{N}$ & 3 & 8 & $y$ & $18-65$ \\
\hline Prosopis juliflora & 1 & 7 & 6 & $\mathrm{n}$ & $18-100$ \\
\hline Salvadora oleoides & $\mathrm{N}$ & 4 & 6 & $y$ & $3-20$ \\
\hline Salvadora persica & $\mathrm{N}$ & 4 & 6 & $n$ & $20-100$ \\
\hline Tamarix sp. & $\mathrm{N}$ & 4 & 4 & $\mathrm{n}$ & $20-100$ \\
\hline Tecomella undulata & $\mathrm{N}$ & 3 & 5 & $\mathrm{n}$ & $5-15$ \\
\hline Ziziphus mauritiana & $\mathrm{N}$ & 5 & 8 & $\mathrm{n}$ & $15-60$ \\
\hline Ziziphus nummularia & $\mathrm{N}$ & 5 & 9 & y & $8-50$ \\
\hline Ziziphus rotundifolia & $\mathrm{N}$ & 6 & 9 & y & $8-55$ \\
\hline
\end{tabular}

Origina $=\mathrm{N}=$ Native; $\mathrm{I}=$ Introduced from iso-climatic regions of world; $\mathrm{O}=$ Introduced from other part of country

Growth rateb $=$ Higher the number, faster the growth rate

Browsing preference/need of protectionc $=\mathrm{n}=$ No need of protection from animal during establishment phase $\boldsymbol{y}=$ need of protection.

Table 3 Woody vegetation and fuel wood production by way of lopping and partial cutting of trees in village 'Sar'

\begin{tabular}{llll}
\hline Species & Estimate Use $(\mathbf{t})$ & \% of Total & \% of Household \\
\hline Prosopis juliflora* & 905.66 & 68.6 & 100 \\
Prosopis cinearia & 375.67 & 28.5 & 82.7 \\
Acacia Senegal & 5.84 & 0.4 & 44 \\
Capparis deciduas & 12.15 & 0.9 & 39.3 \\
Ziziphus nummularia & 2.2 & 0.2 & 36.7 \\
Salvodora oleoides & 4.41 & 0.3 & 16.7 \\
Tecomella undulate & 6.57 & 0.5 & 10.7 \\
Azadirachta indica & 7.61 & 0.6 & 10 \\
\hline
\end{tabular}

*Prosopis juliflora wood is collected in a very large quantity as fuel form of extra-territorial collection 
Table 4 List of tree /shrub species providing some important NTTP in hot Indian arid region

\begin{tabular}{|c|c|c|c|}
\hline Species & Products Fuel & Fruit & Others \\
\hline Acacia leucophloea & 6 & - & $N, M, G$ \\
\hline Acacia nilotica & 10 & $6 *$ & $N, M, G$ \\
\hline Acacia senegal & 6 & 6 & G \\
\hline Acacia tortilis & 7 & $7 *$ & G \\
\hline Ailanthus excelsa & 3 & - & - \\
\hline Albizia lebbeck & 6 & - & - \\
\hline Albizia amara & 7 & - & - \\
\hline Anogeissus pendula & 7 & - & G \\
\hline Azadirachta indica & 5 & - & $\mathrm{M}, \mathrm{O}, \mathrm{G}$ \\
\hline Balanites aegyptiaca & 4 & - & $M, G$ \\
\hline Boswellia serrata & 4 & - & M, G \\
\hline Capparis decidua & 3 & 6 & M \\
\hline Cassia siamea & 7 & - & $\mathrm{N}$ \\
\hline Colophospermum mopane & 6 & - & - \\
\hline Commiphora wightii & 6 & - & M \\
\hline Cordia sp. & 5 & 7 & - \\
\hline Dalbergia sissoo & 7 & - & - \\
\hline Dichrostachys nutans & 4 & - & - \\
\hline Grewia tenax & 5 & - & - \\
\hline Hardwickia binata & 8 & - & - \\
\hline Pongamia pinnata & 7 & - & O \\
\hline Prosopis cineraria & 7 & 7 & G \\
\hline Prosopis juliflora & 9 & 8* & G \\
\hline Salvadora oleoides & 5 & - & $\mathrm{M}, \mathrm{O}$ \\
\hline Salvadora persica & 5 & - & M,O \\
\hline Tamarix sp. & 5 & - & - \\
\hline Tecomella undulata & - & - & - \\
\hline Ziziphus mauritiana & 7 & 9 & - \\
\hline Ziziphus nummularia & 7 & 8 & - \\
\hline Ziziphus rotundifolia & 7 & 8 & - \\
\hline
\end{tabular}

The utility of each species is rated on scale $\mathrm{I}-\mathrm{I} 0$, higher the number, better the utility

$\mathrm{G}=\mathrm{Gum} ; \mathrm{M}=$ Medicinal use; $\mathrm{N}=$ Nitrogen fixing; $\mathrm{O}=\mathrm{Oil}$; =Pod fodder.

Table 5 Gum Arabic production and economic returns in 45 target villages of Barmer, Jodhpur and Nagaur district of arid western Rajasthan

\begin{tabular}{|c|c|c|c|c|c|c|c|c|c|}
\hline \multirow{2}{*}{ Particular } & \multicolumn{8}{|l|}{ Year } & \multirow{2}{*}{ Total } \\
\hline & 2008-09 & 2009-10 & $2010-11$ & $2011-12$ & $2012-13$ & $2013-14$ & $2014-15$ & $2015-16$ & \\
\hline $\begin{array}{l}\text { Number of A. senegal trees } \\
\text { treated (in thousands) }\end{array}$ & 12.1 & 20.95 & $22.6 \mathrm{I}$ & 27.5 & 30 & 34.17 & 20.7 & 19.5 & 187.53 \\
\hline $\begin{array}{l}\text { Production of gum Arabic by } \\
\text { farmers ( } t)\end{array}$ & 5.45 & 10.48 & 7.67 & 11 & 12 & 13.67 & 8.28 & 7.8 & 76.35 \\
\hline $\begin{array}{l}\text { Total income earned by farmers } \\
\text { (Rs. Lakhs) }\end{array}$ & 27.23 & 52.38 & 38.33 & 77 & 84 & 95.69 & 57.96 & 62.4 & 487.19 \\
\hline $\begin{array}{l}\text { Revenue generated by CAZRI } \\
\text { (Rs. Lakhs) }\end{array}$ & 1.21 & 2.1 & 2.25 & 2.75 & 3 & 3.42 & 2.07 & 1.95 & 18.75 \\
\hline
\end{tabular}

\section{CPRs}

They have clearly recognized users of NTTPs, though they may not own such CPRs. The rights of users of NTTP from CPRs may be clearly defined.

\section{Open access resources}

Revenue lands often referred as waste lands are accessible to all to use whatever NTTPs available there as they have no defined users. Therefore, rights to use NTTPs in such lands should be clearly defined so that they could be protected from degradation.

\section{State owned forests}

Though laws and legislations are there to used NTTPs collections by stakeholders however, often forests are subjected to un-controlled collections of NTTPs which many times cause acute stress on forest resources resulting in loss of forest cover. Therefore, capacity building of stakeholders through community based trainings and awareness programmes in context of NTTPs collections are of paramount importance. 


\section{Acknowledgments}

None.

\section{Conflicts of interest}

The authors declare there is no conflict of interests.

\section{Funding}

None.

\section{References}

1. FAO. Non-wood forest products in Asia. RAPA Series No. 28. Bangkok, FAO Regional Office for Asia and the Pacific 1994.

2. Eisa MA, Roth M, Sama G. Acacia senegal (Gum Arabic Tree): Present role and need for future conservation/Sudan. Deutscher Tropentag. 2008.

3. Chandrasekhran C. Terminology, definition and classification of fores products other than wood. In: Report of the expert consolation on non-wood forest products, Yogyakarta, Indonesia. Non- Wood Forest Products. FAO, Rome; 1995.

4. Pandey D. Fuel wood studies in India: Myth and Reality. Centre for International Forestry Research; 2002. 108 p.

5. Sharma AK, Tewari JC. Arid zone forestry with special reference to Indian hot arid zone. In forests and forest plants -vol. IIEncyclopedia of Life Support Systems (EOLSS) Developed under the Auspices of the UNESCO. EOLSS Publishers, Oxford, UK; 2005.

6. Tewari JC, Harsh LN, Venkateswarlu J. Agro forestry research-in the arid region - A reivew. In: Singh RP, Ahlawat IPS \& Saran Ganga, editors. Agro forestry System in India:Research and Development. Indian Society of Agronomy. 1989;9(3):203-212.

7. Tewari JC. Top Feed in Arid Regions of India:A Unique Feature of Man-Crop/Grass-Livestock-Tree/Shrub Continuum of Arid Regions' Farming Systems. Technical Report. Role of top feed in fodder supply systems/ National Sub Group on fodder, New Delhi, India; 2011.

8. Otsyina RM, Norton BW, Djimde M. Fodder trees and shrubs in arid and semi-arid livestock production systems. In: Buchanan-Smith, JG Bailey LD, McCaughey P, editors. Proceedings of the XVIII International Grassland Congress 2, 1999:429-438.

9. Tewari JC, Panwar NR, Manjunatah BL, et al. Enhancing Productivity and Resilience of the Dryland Production Systems through Science Based Development Interventions (CAZRI-ICRISAT-GRAVIS Project), ICAR, CAZRI, Jodhpur; 2015. 34 p.
10. Sirohi AVS, Mathur BK, Mishra AK, et al. Effect of feeding of Prosopis juliflora supplemented fodder block on performance of arid goat. Veterinary Practitioner. 2014;15(2):253-254.

11. Khan MA, Tewari, JC, Singh, R, et al. Structure, production attributes and management strategies in a traditional extensive agro forestry system in an arid region watershed of India. Forest Trees and Livelihood. 2006;16:227-246.

12. Shankarnarayan KA. Agro forestry in Arid and Semi-arid Zones. Central Arid Zone Research Institute, Jodhpur, India 1984. 29 p.

13. Tewari JC, Sharma AK, Narayan P, et al. Restorative forestry and agro forestry in hot arid region og India: A review. Journal of Tropical Forestry India. 2007;23(I\&II):1-16.

14. Jensen M. Wood fuel Productivity of Agro forestry Systems in Asia. A Review of Current Knowledge. Field Document No.45. FAO, Bangkok (Thailand). Regional Wood Energy Development Programme in Asia. 1995.

15. Tewari P, Tewari JC, Tripathi D, et al. Utilisation of domestic fuel wood in typical village of Indian hot arid zone. Journal of Tropical Forest Products. 2003;9(1\&2):1-14.

16. Ram M Tewari JC, Harsh LN, Khan HA, et al. Tree gum tapping technique of CAZRI proved to be a boon of livelihood for gum Arabic tappers of Western Rajasthan in India. Popular Kheti. 2013;1(1):16-20

17. Ram M Tewari JC, Harsh LN. An improved gum tapping from acacia senegal an option for better livelihood. LAP Lambert Academic Publishing, Germany 2012. 78 p.

18. Bhansali RR. Famine foods of rajasthan desert. desert plants. University of Arizona. 2011;77(2).

19. Chauhan KVS, Sharma AK, Kumar R. Non-timber forest products subsistence and commercial uses:Trends and future demands. Int For Rev. 2008;10(2):201-216.

20. Pandey AK, Tripathi YC, Kumar A. Non Timber Forest Products (NTFPs) for Sustained Livelihood:Challenges and Strategies. Research Journal of Forestry. 2016;(1):1-7.

21. Tewari JC, Sharma AK, Harsh LN, et al. Extensive agro forestry system in a transitional belt between arid and semi-arid regions of India:a case study. Journal of Tropical Forestry. 2005;21(3\&4):1-19. 